\title{
Çalışan tutkunluğuyla performans arasındaki ilişkide lider mükemmeliyetçiliğinin düzenleyici rolü
}

\author{
Şeyda HAVUZ ${ }^{a}$, Elif Özge ERBAYb \\ a*istanbul Aydın Üniversitesi Lisansüstü Eğitim Enstitüsü Pskiloloji Bölümü, e posta: seydahavuz@stu.aydin.edu.tr, Orcid: 0000-0002-9207-0895 \\ b*istanbul Aydın Üniversitesi Fen-Edebiyat Fakültesi Psikoloji Bölümü, e posta: eliferbay@aydin.edu.tr, Orcid: 0000-0001-7927-0596
}

\begin{abstract}
MAKALE BÍLGILERI
Araştırma Makalesi

Geliş Tarihi 31 Mayıs 2021

Revizyon 2 Eylül 2021

Kabul tarihi 3 Ekim 2021

Özet

Araştırmanın amacı çalışan tutkunluğuyla performans arasındaki ilişkide lider mükemmeliyetçiliğinin düzenleyici rolü olup olmadığını araştırmaktır. Araştırma İstanbul ilinde çalışan beyaz yakalı 353 özel sektör çalışanı üzerinde uygulanmıştır. Çalışmada APS Mükemmeliyetçilik Ölçeği, UWES Çalışmaya Tutkunluk Ölçeğinin Türkçe versiyonları kullanılmıştır. Araştırma sonucunda çalışan tutkunluğuyla performans arasındaki ilişkide lider mükemmeliyetçiliğinin düzenleyici rolü bulunmadığı görülmüștür. Çalışan tutkunluğu ve performans arasında yapılan çeşitli çalışmalara ek olarak, lider mükemmeliyetçiliği ile çalışan tutkunluğunun, iş performansı üzerindeki olası etkileşim etkisinin araştırılmış olmasının, literatüre kazandırılmış yeni bir sonuç olduğu düşünülmektedir.
\end{abstract}

Anahtar Kelimeler: Lider Mükemmeliyetçiliği, Çalışmaya Tutkunluk, İ̧̧ Performansı

The moderating role of leaders' perfectionalism between employee engagement and job performance

\author{
ARTICLE INFO \\ Research Article \\ Received 31 May 2021 \\ Received in revised form \\ 2 September 2021 \\ Accepted 3 October 2021
}

The aim of this study is to find out if there is a moderator effect of leaders' perfectionalism in the relationship between employee

\section{Abstract} engagement and job performance. This study is applied to 353 white color employees working in private sector companies in istanbul. According to the study, it is found out that there is no moderator effect of leaders' perfectionalism in the relationship between employee engagement and job performance. Besides various studies revealing the relationship between employee engagement and job performance, it is considered that investigation of the interaction effect of leadership perfectionalism and employee engagement on job performance would contribute to the literature as a new consequence.

Keywords: Leaders' Perfectionalism, Employee Engagement, Job Performance

\section{Giriş}

Günümüzde her alanda mükemmeliyetçiliğin önemi artarken, örgütlerde lider mükemmeliyetçiliğinin çalışanların davranış ve tutumlarına nasıl yansıdığı ise merak edilen bir konudur. Örgütlerde çalışanların performanslarının doğrudan veya dolaylı yoldan hangi tutumlardan etkilendiği ise araştırmacıların dikkatini çekmektedir. Lider mükemmeliyetçiliğinin uyumlu ya da uyumsuz olmasına göre çalışanın iş performansı üzerinde farklı etkiler yaratabileceği düşünülmektedir. Bu noktada liderin sağlıklı mükemmeliyetçiliğinin, çalışanın amaca ulaşmasını uyumlu bir yapıyla gerçekleştirmesini sağlayabileceği fikriyle, iş performansını da olumlu etkileyebileceği düşünülmektedir.

İş performansını bireysel performans ve örgütsel performans olarak ikiye ayırmak mümkündür. Örgütlerde bireysel olarak performans gösteren çalışanlar örgütün performansını oluşturmaktadırlar. Bu nedenden ötürü bireysel performans, örgütsel performansı oluşturan etmenlerin en önünde yer almaktadır. Yapılan araştırmalar neticesinde alan yazında bireysel performansın, çalışanın kendini işine adama davranışını niteleyen çalışan tutkunluğu ile bağlantılı olduğu görülmüştür (Koçel, 2018). Çalışan tutkunluğu her ne kadar çalışanın kendi iç dinamikleriyle ilgili gibi görünse de, bu araştırma lider mükemmeliyetçiliğinin iş performansını çalışan tutkunluğu ile etkileşimi üzerinden güçlendireceği hipotezi öne sürülmektedir.

\section{Kavramsal Çerçeve}

Mükemmeliyetçilik

Türk Dil Kurumu (TDK) mükemmel kavramını "eksiksiz, kusursuz, tam, yetkin, şahane bir biçimde" olarak tanımlamaktadır. Ancak mükemmeliyetçilik kavramı Türk Dil Kurumu Sözlüğü’nde tanımlanmamıştır (TDK, 2016). Mükemmel kelimesi, "bilgi ve erdem bakımından olgunluk, yetkinlik, erginlik, eksiksizlik"anlamlarına gelmektedir ve Arapça'dan Türkçe'ye geçen "kemal” kelimesinden türemiştir. Mükemmeliyetçilik (perfectionalism) ise Latince "perfectus" kelimesinden türetilmiştir ve "gerçekleştirilmiş, tamamlanmış ya da bitirilmiş" anlamlarına gelmektedir. Diğer bir bakış açısıla, mükemmeliyetçilik "ulaşılan iyinin daima daha iyisi vardır" şeklinde de açıklanabilmektedir. (Kıral, 2012: 14).

Freud mükemmeliyetçiliği "süper egonun bir özelliği olan ve başarıyı elde etmek için aşırı beklenti" olarak tanımlanmaktadır (Whittaker, 2002: 130). Freud, mükemmeliyetçiliğin takıntılı nevrozdan geldiğinden bahsetmektedir ve mükemmeliyetçiliğin cezalandırıcı ve kontrollü bir süper egonun ürünü olduğunun üzerinde durmaktadır (Whittaker, 2002: 130). Horney (1950) ise, mükemmeliyetçiliğin daha çok nevrotik yönüyle ilgilenmiştir ve hata yapmamak için yapılması gerekenlerin bekletilmesi olarak tanımlamıştır. Başka bir tanımda ise kavramı öncelikle teleolojik doktrinlerin, iyinin ortaya çıkmasında bir ilke olarak gören Rawls (1971:25) , iyi düşüncesinin, insan erdemi ile doğrulanması halinde bunun mükemmeliyetçilik olarak adlandırılabileceğini belirtmektedir.

Hewitt ve Flett'e (1991) göre mükemmeliyetçilik, "kendine yönelik mükemmeliyetçilik, başkalarına yönelik mükemmeliyetçilik ve başkalarınca belirlenen mükemmeliyetçilik" olmak üzere üç boyutta ele alınmıştır: Kendine yönelik mükemmeliyetçilikte, bireyin kendisi için oldukça yüksek standartlar ve gerçekçilik taşımayan amaçlar belirleyerek, ortaya koyduğu her şeyde mükemmel olmaya özen gösterdiği belirtilmektedir. Başkalarına yönelik mükemmeliyetçilik, bireyin çevresindeki bireylerden gerçekçilik taşımayan isteklerinin olduğu ve bireyin kendisi için belirlemiş olduğu yüksek standartlara, karşısındaki bireylerin uyum sağlamalarını beklemesi ile açıklanmaktadır. Başkalarınca belirlenen mükemmeliyetçilikte ise, birey etrafındaki kişilerin oldukça yüksek standartlara sahip olduğunu düşündüğü ve çevresindekilerden onay alabilmek için bu yüksek standartları yerine getirilmesi gereken hedefler olarak gördüğü belirtilmektedir (Hewitt ve Flett, 1991: 99).

Bousman'a göre ise mükemmeliyetçilik, günlük hayatta mükemmel iş, mükemmel çalışma, mükemmel performans ve mükemmel oyun betimlemeleri ile bireylerin kişilik özellikleri ve tutumlarının benzersiz bir birleşimi yansıtması olarak açıklanmaktadır (Bousman, 2007: 14). Davranışsal yaklaşıma göre mükemmeliyetçilik, bireyin kendisi için ve başkalarınca belirlenen gerçekçi olmayan standartlara ulaşmaya çalışması olarak nitelendirilmektedir (Borynack, 
2003: 7). Bilişsel yaklaşıma göre mükemmeliyetçilik ise, bireyin kendisi için ve başkalarınca belirlenen gerçekçi olmayan standartlara yönelik beklentiler, inançlar, yorumlar, tutumlar ve değerlendirmeler olarak ifade edilmektedir (i̧̧̇ler, 2018). Bu tanımlar ışıı̆ında, genel anlamda mükemmeliyetçilik kavramı ilk olarak olumlu bir anlam intiva etse de, sosyal yaşamda bireyin kişiliğine derinden nüfuz ederek olumsuz sonuçlar da ortaya çıkardığı görülmektedir. Bireyin mükemmele ulaşma çabalarının, o kişiyi rahatsız edebileceği belirtilmektedir. Bunun nedeni, bireyin iyi şeyler yapma isteğinin iyi sonuçlara ulaşamamasıyla, bireyin korku ve endişe yaşayabileceği ile açıklanmaktadır. Mükemmeliyetçilik bireyin, bir taraftan motivasyonunu arttırarak performansının yükselmesini sağlarken, diğer taraftan hedeflenen performans seviyesine ulaşılamaması ile bireyin hem bilişsel hem de fiziksel anlamda problemlerle karşılaşmasına neden olabileceği vurgulanmaktadır. Bireyin, ulaştı̆ı hedefleri yeterli görmemesi, başkalarının bireyin performansı hakkındaki olumsuz değerlendirmeleri dikkate alması ve bir işi ilk defa yapmasına rağmen doğru yapamama hissine kapılması gibi olumsuz düşünceler ile kendini kötü hissetme gibi bireye zarar veren durumların ortaya çıkabileceği belirtilmektedir (Kıral, 2012: 16).

\section{Uyumlu ve Uyumsuz Mükemmeliyetçilik}

Mükemmeliyetçiliğin psikometrik ölçümlerine göre yapılan sınıflandırmalarından önce ilk ayrımını yapan Adler (1956), Hollander (1965) ve Hamachek (1978) mükemmeliyetçiliği normal (diğer bir deyişle uyumlu) ve nevrotik (diğer bir deyişle uyumsuz) şeklinde sınıflandırmışlardır. Adler (1954) “normal ve nevrotik mükemmeliyetçilik arasında ince bir çizgi olduğunu belirtmiş ve nevrotik mükemmeliyetçiliğin amaca ulaşmayı güçleştiren, amaca zararı dokunan bir yapı olduğunu" dile getirmiştir. Mükemmel benlik kazanma çabası, diğerlerinden üstün olma ya da daha da önemlisi aşağılık duygusunu saklama amacıyla kullanıldığında, zayıf ve sağlıksız bir hal almaktadır. Mükemmel olma çabası, benlik saygısını korumanın ya da güç kazanmanın bir yolu olarak kullanıldığında sağlıksız olarak nitelendirilmekte ve normal mükemmeliyetçilikten çok nevrotik mükemmeliyetçiliğin belirtisi olarak kabul edilmektedir (Hewitt ve Flett, 1991: 101).

\section{Çalışan Tutkunluğu}

Kahn (1990), çalışanların rollerine ve bu rollere kendilerini ne kadar verdiklerine yoğunlaşmıştır. Kahn ilk araştırmalarında kişisel tutkunluk ile iş performansı ve iş tatmini arasında doğrudan bir ilişki olabileceğini teorik olarak öngörmüştür. Öngördüğü gibi de bu kavramlar ile alakalı yapılan araştırmalarda bu ilişki incelenmiştir (Kahn, 1990: 694). Kahn kişisel tutkunluk kavramını ortaya koymuş, buna da etki eden psikolojik durumu anlamlıık, güven ve elverişlilik boyutları ile açıklamaya çalışmıştır. Anlamlıık; kişinin gösterdiği rol performansının sonucunda fayda görmesi ve yaptığı iş için zaman harcamaya ve uğraşmaya değer hissetmesidir (Kahn, 2012: 20). Kahn'a göre güven boyutu ise, çalışanın kişisel itibar, statü ve kariyeri ile ilgili olarak işten çıkarılma korkusu altında ve olumsuz şartlar altında çalışmadığını hissetmesidir. Güven boyutuna göre çalışanlar, kişiler arası ilişkilerinde destekleyici, güven duygusuna sahip, açık ve esnek şekilde davranmaktadırlar. Elverişlilik ise, kişinin kendini geliştirmek için çalışırken fiziksel, duygusal ve psikolojik kaynaklara sahip olma hissidir. Fiziksel kaynağa sahip olan çalışan, yalnızken ya da diğer çalışanlarla birlikteyken işinin gereğini yapmakta, diğer çalışanlarla empati kurabilmekte ve işini canlı bir şekilde yürütebilmektedir. Psikolojik olarak tutkun olan kişinin motivasyonu da yüksektir. Ayrıca psikolojik olarak tutkun olan çalışan, davranışlarına daha fazla anlam yüklemektedir. Duygusal kaynağa sahip olan birey, iş arkadaşları ve diğer bireylerin inanç ve değerlerine saygı duymakta ve buna uygun davranışlar göstermektedir (Schneider vd. 2012: 162).

"Dinçlik", "adanmışlık" ve "yoğunlaşma" çalışan tutkunluğunun tanımı içerisinde geçen üç boyuttur (Schaufeli ve Bakker, 2004: 71). Dinçlik, yüksek enerji düzeyi, çalışırken kendini zihinsel olarak daha hızlı toparlama, işe karşı çaba sarf etme isteği, çabuk yorulmama ve zorluklarla karşılaşsa bile ısrarcı olma ile tanımlanmaktadır (Schaufeli ve Bakker, 2004: 71). Adanmışlık anlam, şevk, ilham, gurur ve mücadele duygusuyla tanımlanmaktadır. Adanmışık yaşamayan birey işine karşı ne bir heves ne de gurur hissedecektir. Yoğunlaşma tamamıyla odaklanma ve dikkatini yoğun bir şekilde işine verme ile tanımlanmaktadır. Öyle ki zaman işte iken hızlı bir şekilde geçmekte ve kişi sahip olduğu sorunlardan iş vasıtasıyla uzaklaşmaktadır. Çalışan kendini tamamen ve mutlu bir şekilde işine kaptırmakta, çevresindeki her şeyi unutmakta ve zaman hızlı bir şekilde akıp geçtiğinden çalışmadan ayrılmakta zorluk çekmektedir (Schaufeli ve Bakker, 2004: 74).

\section{İş Performansı}

iş performansı, iş görenin kontrolünde bulunan ve organizasyonun amaçlarına ulaşması konusunda katkıda bulunulan davranışlar olarak tanımlanmaktadır. İ̧ performansı kavramı; organizasyonun amaçlarıyla ilgili olan ve iş görenlerin kişisel kontrolünde bulunan davranışları ifade etmektedir. İ̧ performansı hareketli ve dinamiktir. Aynı zamanda birden fazla boyutu vardır. Diğer deyişle, iş performansı zamanla değiştiği için dinamiktir, tek bir sonucu, özelliği ya da faktörü olmadığı için çok boyutlu olarak tanımlanmıştır. Iş performansının davranışsal kabul edilmesinin sebebi ise performansın dışavurumdan kaynaklanmasıdır. Organizasyonun amaçlarına ulaşabilmek adına bütün davranış ve faaliyetler dikkate alınmaktadır. İ̧̧ görenler amaçlarını başarmada yardımcı ya da engelleyici birtakım davranışları benimseyebilirler ancak bu davranışların iş performansları üzerinde etkisi bulunmamaktadır (Barutçugil, 2014: 29).

İ̧̧ görenlerin organizasyonda sergiledikleri performansın tamamı aynı zamanda organizasyonun da iş performansını göstermektedir. İ̧̧ performansı çıktı alınan satış miktarı gibi sonuçlar ile ölçülmektedir. İ̧̧ performansının netleşmesi iş gören davranışlarının anlaşılabilmesi, organizasyon bünyesindeki niteliksel ve niceliksel bütün davranışların anlaşılabilmesi adına önem taşımaktadır. Ancak bugünlerde, iş görenin performansı yalnızca sayısal veriler ve çıktılar ile konuşulmamakta, aynı zamanda iş görenin motivasyonu, örgüte bağlıı̆̆ı, örgütteki sosyal ortam gibi niteliksel öğeler kapsamında da değerlendirmeye alınmaktadır (Helvacıoğlu ve Özutku, 2010: 200).

\section{Liderlik}

Liderlik kavramına dair eski çağlardan günümüze kadar birçok alanda farklı manalar yüklense de liderlik insanlık tarihi kadar eski olan ve hala önemini koruyan bir kavramdır. Antik çağlarda, geniş topluluklar üzerinde büyük tesiri olan kişilere atfedilen liderlik ara sıra çeşitli mitolojik tanrıların yerine konulmuştur. Liderlerin iletişim faziletinin Hermes, strateji oluşturma yetisinin Athena ve kuvvetinin Zeus'la ilişkilendirildiğine rastlanmaktadır. Liderlik kavramı insanlığın varoluşuna kadar giden bir tarihe dayanmasına rağmen, bilim dünyasında 19. ve 20. yüzyılda araştırılmaya başlanmıştır. Bunun nedeni, tam anlamıyla "liderlik" kavramından kaynaklanmaktadır. Günümüzde liderin nasıl olması gerektiği ve nasıl daha verimli olacağı konusu araştırmacıların odak noktası olmakla beraber hala tam manasıyla bir görüş birliğine varılamamıştır. Dönemsel olarak farklı ihtiyaçlar için sürekli yeni teoriler geliştirilmiştir. (Tabak, 2012: 92).

Sosyal, örgütsel, iktisadi ve politik hayatta önemli bir yer tutmasına, bu kapsamda çok fazla tartışma ve araştırma yapılmasına rağmen liderliğin üzerinde uzlaşı sağlanmış tek bir tarifi bulunmamaktadır. Liderlik tanımlarına bakıldığında liderliğin kişiler arası etkileşim ile alakalı olduğu, insanları etkileme ve inandırma sürecinin liderliğin önemli bir parçası olduğu görüşü, ortak bir kabul olarak görülmektedir. Diğer bir ifadeyle liderlik, liderin eylem ve tutumlarının bir sonucudur. Lider, daha önce tanımlanmış olan grup üyelerini toparlayan ve bu grubun üyelerini bir amaca doğru yönlendiren kişidir. Liderlik ise kişileri daha önceden belirlenmiş bir amaca doğru gitmeye ikna etme kabiliyetidir. Liderlik, toplulukların ve örgütlerin olduğu her ortamda ve dönemde kendine yer bulmuş bir hakikattir. Ekip çalışmalarının merkezi, işbirliğinin kıııma noktasıdır. Başka bir bakış açısıyla bu durum, ekip üyeleri ile lider arasında kuvvetli bir etkileşim olduğunun bir göstergesidir. Buradan hareketle liderlik, insanları belli bir ideale doğru ulaştırma motivasyonunu sağlayan bilgi birikimi ve maharetlerinin tamamı olarak ifade edilir (Şahin ve Temizel, 2007: 182).

Liderlik; davranış bilimleri, yönetim ve organizasyon literatüründe bilim insanları tarafından çok çalışılan bir konu olmuştur. Bu zamana kadar liderlik kapsamında 4000'den fazla ampirik çalışma yapılmıştır. Araştırmacılar, sıklıkla liderliği kendi görüşlerine, ilgi alanlarına, önemli olduğunu düşündükleri konular kapsamında ifade etmişlerdir. Stodgill' in (1974) yapmış olduğu kaynak araştırmasında liderin "liderlikle ile ilgili tanım kadar, tanımlamaya çalışan kişi" olduğu belirtilmiştir. Yeni liderlik tanımları Stodgill'in yaptığı açıklama ile sınırlı kalmadan dönemin dinamiklerine göre yapılmaya devam etmektedir.

Lidere ait mükemmeliyetçi kişilik özellikleri lider/çalışan ilişkilerinde örgütlerde çatışma ve çelişkinin ortaya çıkmasına sebep olabilmektedir. Mükemmeliyetçi liderler kusursuzu aradıklarından her detayı kontrol etme ihtiyacı içerisindedirler ve ulaşılamaz standartlara sahip olmaları, kendi içlerinde yaşamış oldukları tatminsizlik ve çelişkili ilişkilerdeki çatışma ortamına zemin hazırlamaktadır.

"Mükemmeliyetçi birey, doğru ve tam yapma duygusu ile kendini alabildiğine zorlar ve işin üstesinden bazen de inanılmayacak şekilde gelir. Başkalarının kendi standartlarına, zamanlamasına ya da belirlenmiş bütçesine uyamayacakları kaygısıyla, onlardan yardım almaksızın işi tek başına 
yapıp bitirme eğilimindedirler. Bu yüzden önemsiz kararları bile başkalarına bırakmakta alık almaz bir biçimde zorlanır. Böylesine kılı kırk yaran titizlik, bütünsel anlamda kurum için ne kadar iyi olursa olsun, gene de diğer insanları ezer ve onlarda bu kişiyle aynı kulvarda yarışamayacakları duygusu uyandırı" (Levinson, 2011:131)

Mükemmeliyetçilik temel olarak başarısız olmaktan kaçma güdüsü olarak ele alınabilir. Mükemmeliyetçi liderler başarısız olmaktan korktukları için işleri defalarca kontrol etme eğilimi içerisindedirler ve sürekli olarak başkalarının davranışlarını kontrol etme ihtiyacı hissederler. (Bieling vd., 2004:1375) Mükemmeliyetçi liderler için olaylar iyi ya da kötü, doğru ya da yanlış veya başarılı ya da başarısız olarak kutuplara ayrılmıştır. Mükemmeliyetçi liderlerin dünyasında yalnızca siyah veya beyaz vardır, gri tonlara ve karışıklıklara yer yoktur (Ben-Sharar, 2014:54-55; Burns, 1999; Pacht, 1984)

\section{Çalışan Tutkunluğu ve Liderlik}

Çalışan tutkunluğu ve liderlik arasındaki ilişkiye bakıldığında; liderlik, çalışmaya tutkunluğun üç belirleyici etkeninden bir tanesidir (Christian, Garza, ve Slaughter, 2011). Diğer taraftan liderler tarafından çalışanlarına gösterilen özen de çalışanlarda tutkunluk ve bağılık oluşmasına neden olmaktadır (Ghadi, Fernando, ve Caputi, 2013). Günümüzde rekabet üst düzeylere ulaşmış ve insan sermayesinin de önemi büyük ölçüde artmıştır. Bu bağlamda örgütlerde çalışmaya tutkun ve örgüte karşı olumlu duygular besleyen çalışanlar da bu rekabet ortamında örgüte pozitif anlamda çok katkı sağlayacaktır (Yıldız, 2017). Örgütlerde liderlerin sergilemiş oldukları liderlik tarzları doğrudan çalışanların motivasyonunu sağlayarak, örgütün belirlenen hedeflere ulaşmasını sağlamaktadır (Demircioğlu, 2015). Bu anlamda, çalışan tutkunluğunu ve motivasyonunu sağlayan en önemli etmenlerin başında liderlik stilinin geldiği görülmektedir.

Dolayısıyla, bu araştırma kapsamında, çalışanların çalışan tutkunluğunun iş performanslarına etkisi ve bu ilişkide liderin mükemmeliyetçiliğinin düzenleyici rolü araştırılmaktadır. Araştırma kapsamında öne sürülen hipotezler şu şekildedir:

H1: Çalışanın performansına göre çalışan tutkunluğu farklılık göstermektedir.

H2: Çalışanların liderine yönelik mükemmeliyetçilik algısı ile çalışan tutkunluğu arasında anlamlı bir ilişki vardır.

H2a: Çalışanların liderine yönelik uyumlu mükemmeliyetçilik algısı ile çalışan tutkunluğu arasında anlamlı bir ilişki vardır.

H2b: Çalışanların liderine yönelik uyumsuz mükemmeliyetçilik algısı ile çalışan tutkunluğu arasında anlamlı bir ilişki vardır.

H3: Çalışanların liderine yönelik mükemmeliyetçilik algısının, çalışan tutkunluğu ile performansları arasında düzenleyici rolü vardır.

H3a: Çalışanların liderine yönelik uyumlu mükemmeliyetçilik algııının, çalışan tutkunluğu ile performansları arasında düzenleyici rolü vardır.

H3b: Çalışanların liderine yönelik uyumsuz mükemmeliyetçilik algııının, çalışan tutkunluğu ile performansları arasında düzenleyici rolü vardır.

\section{Yöntem}

\section{Araştırmanın Modeli}

Araştırmada nicel araştırma yöntemlerinden ilişkisel tarama modeli kullanılmıştır. Nicel araştırma yönteminde temel amaç, olabildiğince yanlıııtan uzak, nesnel, neden-sonuç ilişkisini açıklayan ve örneklemden evrene genellenebilir bilgi elde etmektir (Gall ve Borg 1996).

\section{Evren ve Örneklem}

Bu araştırmanın evrenini İstanbul il sınırları içerisinde yaşayan beyaz yakalı özel sektör çalışanları oluşturmaktadır. Araştırma örneklemi ise, İnternet üzerinde oluşturulan dijital bir anket platformu ile, araştırma evreni içinde yer alan ve kolayda örnekleme yöntemiyle ulaşılan 353 katılımcıdan oluşmaktadır.

\section{Veri Toplama Araçları}

Araştırmanın amacına yönelik olarak elde edilmek istenen verilerin toplanmasında anket tekniği kullanılmışır. Faydalanılan anket formu 3 bölümden oluşmaktadır. Anketin ilk bölümde katıımcıların yaş, cinsiyet, eğitim düzeyi, çalışma bilgileri, gelir düzeyleri ve performans notları sorulmuştur. Anketin ikinci bölümünde ise, "APS Mükemmeliyetçilik Ölçeği"; üçüncü ve son bölümünde ise "UWES Çalışmaya Tutkunluk Envanteri" uygulanmıştır. Il|gili anket formunda yer alan ölçüm araçlarına ilişkin bilgiler aşağıda açıklanmaktadır. Ölçek kullanımlarına ilişkin izinler alınmış olup, çalışmanın yapılabilmesi için etik kurulu onayları tamamlanmıştır. Bu araştırma 2021 Mart-Haziran ayları arasında yapılmışır.

\section{Demografik Bilgi Formu}

Araştırmada kullanılan demografik bilgi formu aşağıda yazııı olan bilgileri toplamayı amaçlamışıı;

a) Katılımonın cinsiyeti

b) Katılımcının yaşı

c) Katııımının eğitim düzeyi

d) Katılımcının gelir düzeyi

e) Katılımcının unvanı

f) Katılımcının son performans dönemine ilişkin performans notu

g) Katııımının aktif olarak çalıştığı kurumdaki toplam çalışma süresi

h) Katıımcının iş hayatındaki toplam çalışma süresi

Demografik bilgi formunda araştırmanın bağlantı kurmayı amaçladığı performans ölçütü anket tekniğiyle değil, doğrudan katılımcıya sorulan performans notu kriteriyle saptanmaya çalışııııșır. Burada amaçlanan kişinin performansını kendi değerlendirmesinin önüne geçilerek, araştırmada konu olan liderin çalışanı nasıl değerlendirdiğinin gösterilmeye çalışımasıdır. Bu çalışma çeşitli sektörlerde uygulanmış olup, \%86 ağırıkla finans sektörü çalışanlarına uygulanmıştır.

\section{APS Mükemmeliyetçilik Ölçeği}

Sapmaz (2006) tarafından Türkçe uyarlaması yapılan ölçeğin orijinali Slaney ve arkadaşları $(1996,1999)$ tarafından kişilerin mükemmeliyetçi davranış tutumlarına sahip olup olmadıklarını saptamak ve sergiledikleri mükemmeliyetçiliğin uyumlu veya uyumsuz olduğunu belirlemek amacıyla geliştirilmiştir. Ölçek, Likert tipinde 1-7 arası değerlendirme ile 1 Tamamen Katılmıyorum, 2 Katılmıyorum, 3 Kısmen Katılmıyorum, 4 Bir Fikrim Yok, 5 Kısmen katılıyorum, 6 Katılıyorum, 7 Tamamen Katılıyorum yanıt verilecek şekilde düzenlenmiştir. Ölçeğin temel 4 alt boyutu vardır. Bunlar; tatminsizlik, düzen, çelişki ve standartlardır.

Ölçeğin ilk formu Slaney ve Johnson (1992) tarafından geliştirilmiştir. Daha sonra Slaney ve arkadaşları tarafından $(1996,2001)$ tarafından güncellenmiştir. Güncellenmiş olan APS Mükemmeliyetçilik ölçeğinde "Yüksek Standartlar" alt ölçeğinden \%67'nin üzerinde puan alanlar mükemmeliyetçi bireyleri ve \%67'nin altında puan alanlar ise mükemmeliyetçi olmayan bireyleri göstermektedir. Ölçeğin uyumlu mükemmeliyetçilik boyutu, düzenlilik ve yüksek standartlar puanlarının birleşiminden oluşmaktadır. Diğer taraftan çelişki ve tatminsizlik alt ölçeğinden alınan yüksek puanlar ise uyumsuz mükemmeliyetçilik boyutunu ifade etmektedir. Ölçeğin Türkçe formunun Sapmaz (2006) tarafından gerçekleştirilen güvenirlik analizlerinde, tatminsizlik, düzen, çelişki ve standartlar alt boyutlarının güvenirlik katsayılarının .69 ile .79 arasında değiştiği; uyumlu mükemmeliyetçilik boyutunun güvenirlik katsayısının .74, uyumsuz mükemmeliyetçiliğin ise .80 olduğu belirtilmiştir.

Faktör analizinin uygulanabilirliğinin ölçümü için Kaiser - Meyer - Olkin (KMO) yeterlilik ölçümüne ve Bartlett's Küresellik testine bakılmıştır. (KMO) ölçümü 1'e ne kadar yakın ise eldeki veri grubuna faktör analizinin yapılmasının uygun olduğu kabul edilmektedir (Živadinović; 2004). Çalışma kapsamında kullanılan mükemmeliyetçilik ölçeğine dair KMO testi sonuçlarına göre (Bkz. Tablo 1 ) ölçeğin faktör analizi için uygun olduğu görülmektedir (KMO=.939). Ölçeğin bu 
Tablo 2. Faktör analizi sonuçlar

\begin{tabular}{|c|c|c|c|}
\hline Boyutlar & $\begin{array}{l}\text { Faktör } \\
\text { Yükleri }\end{array}$ & Öz Değer & $\begin{array}{l}\text { Açıklanan } \\
\text { Varyans (\%) }\end{array}$ \\
\hline \multicolumn{4}{|l|}{ Tatminsizlik } \\
\hline Yapabildiğimizin en iyisini yaptığımızı bilse bile yöneticim tatmin olmaz. & 0.859 & \multirow{6}{*}{9.802} & \multirow{6}{*}{42.616} \\
\hline Elinden gelenin en iyisini yapmak yöneticim için asla yeterli değildir. & 0.827 & & \\
\hline Yöneticim başarılarımızdan asla tatmin olmaz. & 0.843 & & \\
\hline En iyi yapılan şeyler bile hiçbir zaman yöneticime yeterli görünmez. & 0.819 & & \\
\hline Yöneticim performansımızdan neredeyse hiç tatmin olmaz. & 0.875 & & \\
\hline $\begin{array}{l}\text { Bir işi tamamladığında yöneticim genellikle hayal kıııklığı duyar, çünkü daha iyisini } \\
\text { yapabileceğini düşünür. }\end{array}$ & 0.830 & & \\
\hline \multicolumn{4}{|l|}{ Düzen } \\
\hline Yöneticim düzenli bir insandır. & 0.412 & \multirow{4}{*}{4.017} & \multirow{4}{*}{17.466} \\
\hline Tertip(düzen) yöneticim için önemlidir. & 0.762 & & \\
\hline Yöneticime göre her eşya yerli yerine konmalıdır. & 0.417 & & \\
\hline Yöneticim her zaman düzenli ve disiplinli olunmasını ister. & 0.457 & & \\
\hline \multicolumn{4}{|l|}{ Çelişki } \\
\hline Gösterilen performans yöneticimin standartlarına nadiren ulaşır. & 0.838 & \multirow{6}{*}{1.259} & \multirow{6}{*}{5.474} \\
\hline Yöneticimin performansım için koyduğu yüksek standartları nadiren karşılayabiliriz. & 0.858 & & \\
\hline Yöneticimin yüksek standartlarına nadiren ulaşır. & 0.753 & & \\
\hline Yöneticim hedeflerine ulaşamadığı için çoğu kez hayal kırıklığı yaşar. & 0.495 & & \\
\hline Beklentilerinin karşılanmayacağı düşüncesi çoğu kez yöneticimi endişelendirir. & 0.695 & & \\
\hline Yöneticim yapılan şeyin yeterince iyi olduğunu nadiren düşünür. & 0.859 & & \\
\hline \multicolumn{4}{|l|}{ Standartlar } \\
\hline Yöneticimin beklentileri yüksektir. & 0.595 & \multirow{7}{*}{1.017} & \multirow{7}{*}{4.423} \\
\hline Yöneticim bizden en iyisini bekler. & 0.489 & & \\
\hline Yöneticim çalışanları için çok yüksek standartlar koyar. & 0.704 & & \\
\hline Yöneticim yaptığı her şeyin en iyisini yapmaya çalışır. & 0.777 & & \\
\hline Yöneticimin işyerindeki performansına ilişkin standartları yüksektir. & 0.596 & & \\
\hline Mükemmeli elde etmek için yöneticim çok fazla çabalama ihtiyacı hisseder. & 0.614 & & \\
\hline Yöneticime göre kişi kendinden daha fazlasını beklemezse asla başarılı olamaz. & 0.415 & & \\
\hline
\end{tabular}


Tablo 3. APS mükemmeliyetçilik ölçeği alt boyut puan ortalamaları

\begin{tabular}{lccccc}
\hline \multicolumn{1}{c}{ OrtıSS } & $\begin{array}{l}\text { Min-Max } \\
\text { (Medyan) }\end{array}$ & Çarpılık & Basıklık & $\begin{array}{l}\text { Cronbach's } \\
\text { Alpha }\end{array}$ \\
\hline \hline APS Mükemmeliyetçilik Ölçeği & & & & \\
\hline \hline Tatminsizlik & $3.77 \pm 1.75$ & $1-7(3.67)$ & 0.206 & -1.116 & $\mathbf{0 . 9 4 4}$ \\
\hline Düzen & $5.02 \pm 1.22$ & $1-7(5.25)$ & -0.813 & 0.489 & $\mathbf{0 . 8 0 5}$ \\
\hline Çelişki & $4.11 \pm 1.47$ & $1-7(4.17)$ & 0.169 & -0.879 & $\mathbf{0 . 8 8 5}$ \\
\hline Standartlar & $5.31 \pm 0.99$ & $1.57-7(5.43)$ & -0.701 & 0.692 & $\mathbf{0 . 8 0 4}$ \\
\hline Toplam & $4.55 \pm 1,03$ & $1.57-7(4,52)$ & -0.498 & 0.520 & $\mathbf{0 . 9 2 6}$ \\
\hline
\end{tabular}

\section{UWES Çalışmaya Tutkunluk Envanteri}

UWES Çalışmaya Tutkunluk Envanteri Schaufeli ve arkadaşları (2002) tarafından geliştirilmiştir. Turgut (2011) tarafından Türkçe'ye uyarlanmıştır. Ölçeğin orijinal adı Utrecht Work Engagemen Scale (UWES) dir. Ölçek toplamda 17 ifade içermektedir ve değerlendirmesi için Likert tipinde 1 ila 6 arasındaki ifadeler kullanılmıştır. Bu ifadeler; 1 Hiçbir zaman, 2 Nadiren, 3 Bazen, 4 Sık sık, 5 Çok sık ve 6 Her zaman şeklinde sıralanmaktadır. Ölçeğin dinçlik, adanmışlık ve yoğunlaşma adları altında 3 alt boyutu bulunmaktadır. Ölçekte bulunan 17 ifadeden, 6 tanesi dinçlik boyutunu, 5 tanesi adanmışlık boyutunu ve 6 tanesi yoğunlaşma alt boyutunu ölçümlemeyi amaçlamaktadır. Ölçeğin Türkçe formunun Turgut (2011) tarafından gerçekleştirilen güvenirlik analizlerinde; alt boyutlarının güvenirlik katsayılarııı .81 ile .87 arasında değiştiği, ölçeğin genelinin güvenirlik katsayısının ise .88 olduğu belirtilmiştir.

Çalışma kapsamında kullanılan çalışan tutkunluğu ölçeğine dair KMO testi sonuçlarına göre (Bkz. Tablo 4) ölçeğin faktör analizi için uygun olduğu görülmektedir (KMO=.928).

Tablo 4. KMO ve Bartlett testi sonuçları

Kaiser-Meyer-Olkin Measure of Sampling Adequacy.

$\begin{array}{ll} & 0.928 \\ \text { Chi-Square } & 4564.999 \\ \text { Df } & 136 \\ \text { Sig. } & <0.000\end{array}$

Yapılan açıklayııı faktör analizi sonuçlarına göre ölçeğin orijinaline uygun şekilde 3 faktörlü bir yapıdan oluştuğu görülmektedir. Faktörün özdeğeri ve varyans açıklama oranı \%70.08 olarak hesaplanmıştır (Bkz. Tablo 5).

Tablo 5. Faktör analizi sonuçları

\begin{tabular}{|c|c|c|c|}
\hline Boyutlar & $\begin{array}{l}\text { Faktör } \\
\text { Yükleri }\end{array}$ & Öz Değer & $\begin{array}{c}\text { Açıklanan } \\
\text { Varyans (\%) }\end{array}$ \\
\hline \multicolumn{4}{|l|}{ Dinçlik } \\
\hline Sabah uyandığımda işe gitmek için istekli olurum. & 0.707 & & \\
\hline İşimi yaparken enerji dolu olurum. & 0.742 & & \\
\hline Her şey yolunda gitmese bile işimde daima sebat ederim. & 0.626 & 8.908 & 52.400 \\
\hline Çok uzun saatler çalışabilirim. & 0.653 & & \\
\hline İşimde zihinsel olarak oldukça dayanıkıııım. & 0.716 & & \\
\hline İşimde kendimi güçlü ve dinç hissederim. & 0.817 & & \\
\hline
\end{tabular}

\begin{tabular}{|c|c|c|c|}
\hline \multicolumn{2}{|l|}{ Adanmışık } & \multirow{6}{*}{2.126} & \multirow{6}{*}{12.504} \\
\hline İşimin ilgi çekici ve gayret gerektiren bir iş olduğunu düşünüyorum. & 0.750 & & \\
\hline İşim bana ilham verir. & 0.825 & & \\
\hline İşimi hevesle yaparım. & 0.833 & & \\
\hline Yaptığım işle gurur duyarım. & 0.825 & & \\
\hline Yaptığım işin anlamlı olduğunu ve bir amaca hizmet ettiğini düşünüyorum. & 0.769 & & \\
\hline \multicolumn{4}{|l|}{ Yoğunlaşma } \\
\hline Çalışırken çevremdeki her şeyi unutuveririm. & 0.605 & \multirow[b]{2}{*}{0.876} & \multirow[b]{2}{*}{5.154} \\
\hline Çalışırken zamanın nasıl geçtiğini anlamam. & 0.766 & & \\
\hline Çalışırken yaptığım işe kendimi kaptırıım. & 0.771 & & \\
\hline
\end{tabular}


Tablo 6. UWES çalışan tutkunluğu ölçeği alt boyut puan ortalamaları

\begin{tabular}{lccccc}
\hline \multicolumn{1}{c}{ OrțSS } & $\begin{array}{l}\text { Min-Max } \\
\text { (Medyan) }\end{array}$ & Çarpılık & Basıklık & $\begin{array}{l}\text { Cronbach's } \\
\text { Alpha }\end{array}$ \\
\hline \hline UWES Çalışan Tutkunluğu Ölçeği & & & & \\
\hline \hline Dinçlik & $3.7 \pm 0.81$ & $1.17-6(3.67)$ & 0.015 & 0.864 & 0.866 \\
\hline Adanmışlık & $3.72 \pm 1.08$ & $1-6(3.8)$ & -0.041 & -0.021 & $\mathbf{0 . 9 2 6}$ \\
\hline Yoğunlaşma & $3.48 \pm 0.88$ & $1.33-6(3.5)$ & 0.227 & 0.123 & $\mathbf{0 . 8 7 8}$ \\
\hline Toplam & $3.63 \pm 0.81$ & $1.2-5.94(3.6)$ & 0.023 & 0.532 & $\mathbf{0 . 9 4 1}$ \\
\hline
\end{tabular}

\section{Bulgular}

\section{Demografik Bulgular}

Ankete katılanların \% 60'ını kadınlar, \%40'ını ise erkekler oluşturmaktadır. Katılımcıların \% 26.06'sı 34 yaş ve altında, \% $38.81^{\prime} i 35$ ila 44 yaş arasında ve \% 37.96 'sı 45 yaş üzerindedir. Katılımcıların \% 59.20'si lisans mezunu iken, \% 32.86'sı lisansüstü ve doktora mezunudur. Katılımcıların \% 73'ü ortalama gelir düzeyine sahiptir ve \% 43.9'u son performans döneminde beklenti üzerinde performans notu almıştır. Katılımcıların \% 37 'si 21 sene ve üzeri iş tecrübesi olduğunu ifade ederken, bu bireylerin içerisinden \% $44.8^{\prime} \mathrm{i}$ şu an çalıştıkları kurumdaki deneyimlerinin 0-5 yıl arasında olduğunu ifade etmiştir (Bkz. Tablo 7).

\begin{tabular}{|c|c|c|}
\hline & Frekans & $\%$ \\
\hline Kadın & 212 & 60.1 \\
\hline Erkek & 141 & 39.9 \\
\hline 34 yaş ve altı & 92 & 26.1 \\
\hline $35-44$ yaş & 137 & 38.8 \\
\hline 45 yaş ve üzeri & 124 & 35.1 \\
\hline Lise ve altı & 14 & 4.0 \\
\hline Ön lisans & 14 & 4.0 \\
\hline Lisans & 209 & 59.2 \\
\hline Lisansüstü/Doktora & 116 & 32.9 \\
\hline Alt & 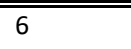 & 1.7 \\
\hline Orta & 260 & 73.7 \\
\hline Yüksek & 87 & 24.6 \\
\hline Yetkili ve Yetkili Yardımcısı & 67 & 19.0 \\
\hline Yönetici & 102 & 28.9 \\
\hline Birim Müdürü & 63 & 17.8 \\
\hline Bölüm Başkanı & 30 & 8.5 \\
\hline Diğer & 91 & 25.8 \\
\hline $0-5$ & 158 & 444.8 \\
\hline 6-10 & 88 & 24.9 \\
\hline $11-15$ & 37 & 10.5 \\
\hline $16-20$ & 31 & 8.8 \\
\hline 21 ve üzeri & 39 & 11.0 \\
\hline $0-5$ & 83 & 23.5 \\
\hline $11-15$ & 78 & 22.1 \\
\hline $16-20$ & 59 & 16.7 \\
\hline 21 ve üzeri & 133 & 37.7 \\
\hline
\end{tabular}




\begin{tabular}{lll}
\hline \hline Beklenti altında & 19 & 5.4 \\
Beklenti düzeyinde & 95 & 26.9 \\
Beklenti üzerinde & 155 & 43.9 \\
Beklentinin çok üzerinde & 84 & 23.8
\end{tabular}

\section{Hipotez Testleri}

H1: Çalışanın performansına göre çalışan tutkunluğu farklıık göstermektedir.

Araştırmanın ilk hipotezini test etmek üzere yapılan tek yönlü varyans analizi sonucuna göre; performansa göre, çalışan tutkunluğunun anlamlı şekilde farkılıaştığı $[F(3,352)=6.122, p<.05]$ tespit edilmiştir (Bkz. Tablo 8). Buna göre performansları beklentinin altında olanların çalışan tutkunluğu toplam puanı, performansları beklentinin üzerinde ve çok üzerinde olan çalışanların çalışan tutkunluğu düzeylerinden anlamlı şekilde yüksektir. Performanslarını beklenti düzeyinde raporlayan çalışanların çalışan tutkunluğu ise, beklentinin çok üzerinde performans gösteren çalışanlardan anlamlı şekilde düşüktür. Dolayısıyla araştırmanın ilk hipotezi destek görmüştür.

Çalışan performansına göre çalışan tutkunluğunun tüm boyutlarının da farklılık gösterdiği tespit edilmiştir. Performans göre, çalışan tutkunluğunun dinçlik boyutunun farklılaştığı $[F(3,352)=5.355, p<.05]$ tespit edilmiştir. Buna göre beklentinin çok üzerinde kalanların dinçlik düzeyi, beklenti altında ve beklenti düzeyinden anlamlı şekilde yüksektir. Performans göre, çalışan tutkunluğunun adanmışlık boyutunun farklılaştığı $[F(3,352)=5.658$ p <.05] tespit edilmiştir. Buna göre beklentinin altında kalanların adanmışlık düzeyi, beklenti üzerinde ve beklenti çok üzerinden anlamlı şekilde düşüktür. Performans göre, çalışan tutkunluğunun yoğunlaşma boyutunun farklılaştığı $[F(3,352)=3.658$ p<.05] tespit edilmiştir. Buna göre beklentinin altında kalanların yoğunlaşma düzeyi, beklentinin çok üzerinden anlamlı şekilde düşüktür.

Tablo 8: Çalışanın performansına göre çalışan tutkunluğunun değerlendirilmesi

\begin{tabular}{|c|c|c|c|c|c|c|}
\hline Değişkenler & Performans & $\overline{\mathbf{x}}$ & SS & $F$ & $p$ & Grup Fark \\
\hline \multirow{4}{*}{ Dinçlik } & (1)Beklenti Altında & 3.29 & 0.93 & \multirow{4}{*}{5.355} & \multirow{4}{*}{$0.001^{* *}$} & \multirow{4}{*}{$\begin{array}{l}1 \rightarrow 4 \\
2 \rightarrow 4\end{array}$} \\
\hline & (2)Beklenti düzeyinde & 3.56 & 0.83 & & & \\
\hline & (3)Beklenti üzerinde & 3.70 & 0.80 & & & \\
\hline & (4)Beklentinin çok üzerinde & 3.95 & 0.72 & & & \\
\hline \multirow{4}{*}{ Adanmışlık } & (1)Beklenti Altında & 2.92 & 1.06 & \multirow{4}{*}{5.658} & \multirow{4}{*}{$0.001^{* *}$} & \multirow{4}{*}{$\begin{array}{l}1 \rightarrow 3 \\
1 \rightarrow 4\end{array}$} \\
\hline & (2)Beklenti düzeyinde & 3.59 & 1.17 & & & \\
\hline & (3)Beklenti üzerinde & 3.76 & 1.03 & & & \\
\hline & (4)Beklentinin çok üzerinde & 3.97 & 0.99 & & & \\
\hline \multirow{4}{*}{ Yoğunlaşma } & (1)Beklenti Altında & 3.03 & 0.92 & \multirow{4}{*}{3.658} & \multirow{4}{*}{$0.013^{*}$} & \multirow{4}{*}{$1 \rightarrow 4$} \\
\hline & (2)Beklenti düzeyinde & 3.40 & 0.97 & & & \\
\hline & (3)Beklenti üzerinde & 3.48 & 0.87 & & & \\
\hline & (4)Beklentinin çok üzerinde & 3.69 & 0.74 & & & \\
\hline \multirow{4}{*}{ Toplam } & (1)Beklenti Altında & 3.08 & 0.78 & \multirow{4}{*}{6.122} & \multirow{4}{*}{$0.001^{* *}$} & \multirow{4}{*}{$\begin{array}{l}1 \rightarrow 3 \\
1 \rightarrow 4 \\
2 \rightarrow 4\end{array}$} \\
\hline & (2)Beklenti düzeyinde & 3.52 & 0.89 & & & \\
\hline & (3)Beklenti üzerinde & 3.65 & 0.80 & & & \\
\hline & (4)Beklentinin çok üzerinde & 3.87 & 0.70 & & & \\
\hline
\end{tabular}

${ }^{a}$ One-Way Anova testi ${ }^{* *} p<0.01$

H2: Çalışanların liderine yönelik mükemmeliyetçilik algısı ile çalışan tutkunluğu arasında anlamlı ilişki vardır.

Lider mükemmeliyetçiliği ile çalışan tutkunluğu arasında istatistiksel olarak anlamlı $(r=-0.110, p<0.01)$ bir ilişkinin olduğu görülmektedir (Bkz. Tablo 9). Diğer deyişle, çalışanın liderine yönelik mükemmeliyetçilik algısı ile çalışan tutkunluğu arasında negatif yönlü anlamlı bir ilişki bulunmaktadır ve araştırmanın ikinci hipotezi destek görmüştür. Lider mükemmeliyetçiliğinin çalışan tutkunluğu alt boyutlarıyla ilişkilerine bakılacak olursa; çalışan tutkunluğunun dinçlik boyutu $(r=-0.173, p<0.01)$ ve adanmışlık boyutu $(r=-0.179, p<0.01)$ ile negatif yönlü ve anlamlı şekilde ilişkili olduğu, ancak yoğunlaşma boyutu ile anlamlı bir ilişkisinin olmadığı görülmüştür $(p=0.501 ; p>0.05)$. Lider mükemmeliyetçilik düzeyinin tatminsizlik boyutu ile çalışan tutkunluğunun toplam puanı arasında negatif yönlü anlamlı bir ilişkinin olduğu görülmektedir $(r=-0.252, p<0.01)$. Ayrıca mükemmeliyetçilik düzeyinin tatminsizlik boyutu ile çalışan tutkunluğunun dinçlik $(r=-0.294, p<0.01)$ ve tatminsizlik boyutu $(r=-0.313, p<0.01)$ ile de aralarında negatif yönlü anlamlı ilişkilerin olduğu görülmektedir. Diğer yandan, mükemmeliyetçilik düzeyinin tatminsizlik boyutu ile çalışan tutkunluğunun yoğunlaşma boyutu ile arasında ise anlamlı bir ilişkinin olmadığı görülmüştür. $(\mathrm{p}=0.380, \mathrm{p}>0.05)$.

Mükemmeliyetçilik düzeyinin düzen boyutu ile çalışan tutkunluğu toplam puanı arasında pozitif yönlü anlamlı bir ilişki tespit edilmiştir ( $r=0.77, p<0.01$ ). Ayrıca, mükemmeliyetçilik düzeyinin düzen boyutu ile çalışan tutkunluğunun adanmışlık boyutu arasında da negatif yönlü anlamlı bir ilişkinin olduğu görülmektedir $(r=-0.153, p<0.01)$. Ancak, düzen boyutunun, çalışan tutkunluğunun ne dinçlik boyutu ile ne de yoğunlaşma boyutu ile anlamlı bir ilişkiye sahip olmadığı görülmüştür.

Mükemmeliyetçilik düzeyinin çelişki boyutu ile çalışan tutkunluğu toplam puanı arasında istatistiksel olarak anlamlı bir ilişkinin olduğu $(r=-0.220, p<0.01)$; ayrıca çalışan tutkunluğunun dinçlik boyutu $(r=-0.241, p<0.01)$ ve adanmışlık boyutu $(r=-0.255, p<0.01)$ ile de arasında negatif yönlü anlamlı birer ilişkisinin olduğu görülmektedir. Diğer yandan, lider mükemmeliyetçiliği çelişki boyutunun çalışan tutkunluğunun yoğunlaşma boyutu ile istatistiksel olarak anlamlı bir ilişkiye sahip olmadığı görülmüştür.

Mükemmeliyetçilik düzeyinin standartlar boyutu ile çalışan tutkunluğu toplam puanı arasında istatistiksel olarak anlamlı $(r=0.140, p<0.01)$ bir ilişkinin olduğu görülmektedir. Ayrıca, standartlar boyutunun, çalışan tutkunluğunun dinçlik boyutu $(p=0.389 ; p>0.05)$; adanmışlık boyutu $(r=0.121, p<0.05)$; ve yoğunlaşma boyutu $(r=0.198, p<0.01)$ ile de arasında istatistiksel olarak anlamlı birer ilişkinin olduğu görülmektedir. 


\begin{tabular}{|c|c|c|c|c|c|c|c|c|c|c|c|c|c|c|}
\hline & \multicolumn{2}{|c|}{ 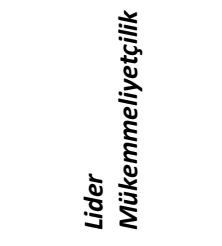 } & \multicolumn{2}{|c|}{ 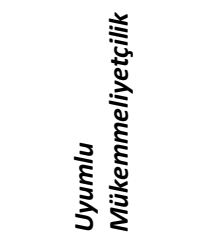 } & \multicolumn{2}{|c|}{ 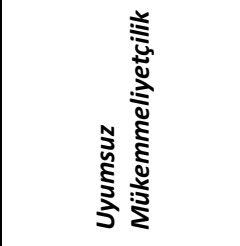 } & \multicolumn{2}{|c|}{ 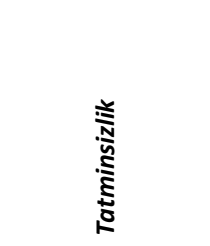 } & \multicolumn{2}{|c|}{ ฐ్̃̃ } & \multicolumn{2}{|c|}{ 离 } & \multicolumn{2}{|c|}{ 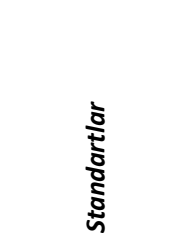 } \\
\hline & $r$ & $p$ & $r$ & $p$ & $r$ & $p$ & $r$ & $p$ & $r$ & $p$ & $r$ & $p$ & $r$ & $p$ \\
\hline $\begin{array}{l}\text { Çalışan } \\
\text { Tutkunluğu }\end{array}$ & -0.110 & $0.039 *$ & 0.146 & $0.006^{* *}$ & -0.234 & $0.001 * *$ & -0.252 & $0.001 * *$ & 0.177 & $0.028^{*}$ & $\begin{array}{l}- \\
0.20 \\
0\end{array}$ & $\begin{array}{l}0.001 * \\
*\end{array}$ & $\begin{array}{l}0.14 \\
0\end{array}$ & $\begin{array}{l}0.009 * \\
*\end{array}$ \\
\hline Dinçlik & -0.173 & $0.001 * *$ & 0.080 & 0.135 & -0.277 & $0.001^{* *}$ & -0.294 & $0.001 * *$ & 0.088 & 0.097 & $\begin{array}{l}- \\
0.24 \\
1\end{array}$ & $\begin{array}{l}0.001 * \\
*\end{array}$ & $\begin{array}{l}0.04 \\
6\end{array}$ & 0.389 \\
\hline Adanmışlık & -0.149 & $0.005^{* *}$ & 0.159 & $0.003^{* *}$ & -0.295 & $0.001 * *$ & -0.313 & $0.001 * *$ & -0.153 & $\begin{array}{l}0.004 * \\
*\end{array}$ & $\begin{array}{l}- \\
0.25 \\
5\end{array}$ & $\begin{array}{l}0.001 * \\
*\end{array}$ & $\begin{array}{l}0.12 \\
1\end{array}$ & $0.023 *$ \\
\hline Yoğunlaşma & 0.036 & 0.501 & 0.137 & $0.010^{*}$ & -0.037 & 0.491 & -0.047 & 0.380 & 0.056 & 0.295 & $\begin{array}{l} \\
0.02 \\
3\end{array}$ & 0.672 & $\begin{array}{l}0.19 \\
8\end{array}$ & $\begin{array}{l}0.001 * \\
*\end{array}$ \\
\hline
\end{tabular}

H2.a: Çalışanların liderine yönelik uyumlu mükemmeliyetçilik algısı ile çalışan tutkunluğu arasında anlamlı bir ilişki vardır.

Çalışanın liderine yönelik uyumlu mükemmeliyetçilik algısı ile çalışan tutkunluğunun arasında pozitif yönlü anlamlı $(r=0.146, p<0.01)$ bir ilişkinin olduğu görülmektedir. Buna göre H2.a hipotezi de destek görmektedir. Ayrıca, uyumlu mükemmeliyetçilik algısının çalışan tutkunluğunun dinçlik boyutu ile ( $p=0.135$; $p>0.05)$; adanmışlık boyutu $(r=0.159, p<0.01)$ ile ve yoğunlaşma boyutu ile de anlamlı $(r=0.137, p<0.01)$ birer ilişkinin olduğu tespit edilmiştir.

H2.b: Çalışanların liderine yönelik uyumsuz mükemmeliyetçilik algısı ile çalışan tutkunluğu arasında anlamlı bir ilişki vardır.

Çalışanın liderine yönelik uyumsuz mükemmeliyetçilik algısı ile çalışan tutkunluğu arasında negatif yönlü anlamlı $(r=-0.234, p<0.01)$ bir ilişkinin olduğu görülmektedir. Buna göre $\mathrm{H} 2$.b destek görmektedir. Ayrıca, uyumsuz mükemmeliyetçilik algısı ile çalışan tutkunluğunun dinçlik boyutu $(r=-0.277, p<0.01)$ ve adanmışlık boyutu $(r=-0.295, p<0.01)$ ile de arasında negatif yönlü anlamlı ilişkileri olduğu görülmüştür. Ancak uyumsuz mükemmeliyetçilik ile çalışan tutkunluğunun yoğunlaşma boyutu arasında istatistiksel olarak anlamlı bir ilişki olmadığı tespit edilmiştir.

Hipotez 3: Çalışanların liderine yönelik mükemmeliyetçilik algısının, çalışan tutkunluğu ile performansları arasındaki ilişkide düzenleyici rolü vardır.

Araştırma kapsamındaki üçüncü hipotezi test etmek için yapılan regresyon analizinde, düzenleyici etkiden önce çalışan tutkunluğu ile performans arasındaki etki incelenmiştir. Bağımsız değiş̧ken olarak ele alınan "Çalışan Tutkunluğu" ile bağımlı değişken olarak ele alınan "Performans" arasındaki regresyon modeli anlamlı bulunmuştur ( $\beta=0.230 ; p<0.01$; Adjusted $\left.R^{2}: 0.045\right)$. Regresyon modeli anlamlı bulunduğu için liderine yönelik mükemmeliyetçilik bakış açısının bu modeldeki düzenleyici rolü incelenmiştir (Bkz. Tablo 10).

Tablo 10: Regresyon analizi

\begin{tabular}{lcccc}
\hline Katsayı & $\beta$ & $\mathrm{S} . \mathrm{H}$. & $\mathrm{t}$ & $\mathrm{p}$ \\
\hline \hline Sabit & 3.011 & 0.204 & 14.750 & $0.000^{* *}$ \\
Çalışan Tutkunluğu & 0.230 & 0.055 & 4.198 & $0.001^{* *}$ \\
\hline
\end{tabular}

Liderine yönelik mükemmeliyetçilik bakış açısının, çalışan tutkunluğu ile performans arasındaki ilişkide düzenleyici bir rolü olmadığı görülmektedir ( $p>0,01$ ). Bu sonuçlara göre araştırmanın 3. hipotezi reddedilmiştir.

\begin{tabular}{lllll}
\multicolumn{5}{c}{ Tablo 11: Düzenleyici rolü } \\
\hline Katsayı & $\beta$ & $\mathrm{S} . \mathrm{H}$. & $\mathrm{t}$ & $\mathrm{p}$ \\
\hline \hline Sabit & 3.859 & 0.048 & 83.842 & $0.000^{* *}$ \\
Mükemmeliyetçilik & -0.09 & 0.043 & -2.2314 & $0.002^{* *}$ \\
Çalışan Tutkunluğu & 0.2238 & 0.057 & 3.9269 & $0.001^{* *}$ \\
Int_1 & $\mathbf{- 0 . 0 3 5}$ & $\mathbf{0 . 0 4 9}$ & $\mathbf{- 0 . 7 2 9}$ & $\mathbf{0 . 4 6 6 3}$ \\
\hline & & ${ }^{* * \mathrm{p}<0,01{ }^{*} \mathrm{p}<0,05}$
\end{tabular}

H3.a: Çalışanların liderine yönelik uyumlu mükemmeliyetçilik algısının, çalışan tutkunluğu ile performansları arasındaki ilişkide düzenleyici rolü vardır.

Liderine yönelik uyumlu mükemmeliyetçilik bakış açısının, çalışan tutkunluğu ile performans arasındaki ilişkide düzenleyici bir rolü olduğu görülmektedir $(p=0,001 ; p<0,01)$. (Bkz. Tablo 12). Bu sonuçlara göre H3.a hipotezi kabul edilmiştir. Uyumlu mükemmeliyetçiliğin, algılanan çalışan tutkunluğu ile performansları ilişkisi üzerinde pozitif yönlü 0,229 etki düzeyince düzenleyici rolü vardır. 
Tablo 12: Düzenleyici rolü

\begin{tabular}{|c|c|c|c|c|}
\hline Katsayı & $\beta$ & S.H. & $\mathrm{t}$ & $\mathrm{p}$ \\
\hline Sabit & 3.001 & 0.029 & 10,1241 & $0.000^{* *}$ \\
\hline Uyumlu Mükemmeliyetçilik & 0.254 & 0.014 & 3,1158 & $0.001^{* *}$ \\
\hline Çalışan Tutkunluğu & 0.052 & 0.033 & 3,2101 & $0.015^{*}$ \\
\hline int_1 & 0.229 & 0.055 & 4,1403 & $0.001^{* *}$ \\
\hline
\end{tabular}

$$
* * p<0,01{ }^{*} p<0,05
$$

H3.b: Çalışanların liderine yönelik uyumsuz mükemmeliyetçilik algısının, çalışan tutkunluğu ile performansları arasındaki ilişkide düzenleyici rolü vardır. Liderine yönelik uyumsuz mükemmeliyetçilik bakış açısının, çalışan tutkunluğu ile performans arasındaki ilişkide düzenleyici bir rolünün olmadığı görülmektedir ( $p>0,05)$. (Bkz. Tablo 13). Bu sonuçlara göre H3.b hipotezi reddedilmiştir.

\begin{tabular}{|c|c|c|c|c|}
\hline Katsayı & $\beta$ & S.H. & $\mathrm{t}$ & $\mathrm{p}$ \\
\hline Sabit & 3.001 & 0.045 & 84,9245 & $0.000 * *$ \\
\hline Uyumsuz Mükemmeliyetçilik & -0.454 & 0.014 & 2,1158 & $0.020^{*}$ \\
\hline Çalışan Tutkunluğu & 0.183 & 0.057 & 3,5112 & $0.025^{*}$ \\
\hline int_1 & -0.082 & 0.015 & 0,5199 & 0.603 \\
\hline
\end{tabular}

${ }^{* *} p<0,01{ }^{*} p<0,05$

\section{Tartışma ve Sonuç}

Çalışanın performansına göre çalışan tutkunluğu farkılık göstermektedir hipotezi çalışma neticesinde desteklenmiştir. Çalışan performansı ile çalışan tutkunluğu arasındaki ilişkiyi gösteren diğer çalışmalar da (Bakker, Tims ve Derks, 2012; Lorente vd., 2014; Rich vd., 2010) bu bulguyu destekler niteliktedir. Çalışmaya tutkun bir bireyin, iş kalitesinin ve yaratıcılığının yüksek olması beklenmektedir. Alan yazın tarandığında birçok çalışmada çalışmaya tutkunluk ve performans arasında pozitif yönlü ilişki saptanmıştır (Arıkan ve Çankır, 2009) Bu bağlamda, çalışmaya tutkun bireylerin genellikle coşku, sevinç, heyecan ve mutluluk gibi duygular taşıdığı ve bunun da sağlıklarını pozitif yönde etkilediği belirtilmektedir. (Bakker ve Demerouti, 2008: 215). Çalışmaya tutkun bireyler yüksek performans sergilerken, çalışan tutkunluğu olmayan bireyler ise düşük performans sergilemektedirler. Bu noktada çalışanların çalışmaya tutkun olmalarını sağlayan faktörlerin neler olduğu önem kazanan bir konudur. Çalışan tutkunluğu yüksek olan bireylerin, kendilerini işlerine yüzde yüz verdiği, işlerini dinamik bir şekilde yaptıkları ve verimliliklerinin yüksek olduğu belirtilmektedir (Keser ve Yılmaz, 2009). Dolayısıyla işini şevkle yapan ve yaptıkları işe kendilerini adayan yani çalışamaya tutkun bireylerin yüksek performans göstermesi şaşırtıcı bir sonuç olmamışıır.

Araştırmanın ikinci hipotezine göre çalışanların liderine yönelik mükemmeliyetçilik algısı ile çalışan tutkunluğu arasında negatif yönlü anlamlı bir ilişkinin olduğu görülmektedir ve hipotez destek görmüştür. Lider mükemmeliyetçiliğinin aynı zamanda çalışan tutkunluğunun dinçlik ve adanmışlık boyutları ile de negatif yönlü bir ilişkide olduğu görülmüştür. Buradan yola çıkarak, liderlik özelliklerinin çalışanların adanmışıklarını etkilediği kanısına varılabilir, adanmış bir çalışan işini şevkle yapacağı için daha dinamik olması kaçınıımazdır. Çalışanların yapmakta oldukları iş; onlara ilham kaynağı olur ve işlerini heves ve coşkuyla yaparlar, bu da onların işlerinden gurur duymalarına yol açar. (Schaufeli vd. 2002: 74-75). Çalışanın işe adanmışlık duygusu, güven, yönetim stili, liderlik stili ve örgüt kültürü gibi etmenlerden beslenmektedir (Lockwood 2007: 8). Bu sebeplerden ötürü, örgütte yer alan liderlerin liderlik özellikleri çalışanların işe adanmışık duygularıyla ilişkilidir (Ghafoor vd. 2011: 7393). Bunlardan yola çıkarak, çalışanda liderine yönelik mükemmeliyetçilik algısı arttığında çalışanın adanmışıı̆ı ve dinçliği azalmakta iken, daha az mükemmeliyetçi algılanan liderlerde, çalışan adanmışlı̆̆ı ve dinçliği artmaktadır. Diğer taraftan lidere yönelik mükemmeliyetçilik algısının yoğunlaşma boyutu ile anlamlı bir ilişkisi saptanamamıştır. Yoğunlaşan çalışan, kendini mutlu ve oldukça yoğun bir şekilde kendini işine adaması ve kendini işinden alıkoymakta zorluk çekmesiyle tanımlanır (Schaufeli vd. 2002: 74-75). Yoğunlaşmanın bireyin tamamen iç dinamikleriyle alakalı olduğu düşünülürse, bunda lider mükemmeliyetçiliğinin herhangi bir etkisinin olmaması doğal karşılanmaktadır.

Lidere yönelik mükemmeliyetçilik düzeyinin tatminsizlik boyutu ile çalışan tutkunluğu arasında negatif yönlü anlamlı bir ilişkinin olduğu araştırma sonucunda ortaya çıkmışır. Tatminsizlik boyutunun uyumsuz mükemmeliyetçiliği gösterdiği düşünüldüğünde, araştırma neticesinde varılan sonuç şaşırtıcı değildir. Zira liderinin uyumsuz mükemmeliyetçiliğe sahip olduğunu düşünen çalışanların çalışan tutkunluğunun da düşük olduğu görülmektedir. Tatminsiz liderler, çalışma neticesinde çıkan sonuçlardan memnun olmamakta ve ulaşılamayacak standartlar talep etmektedirler. Bunun da çalışanlar üzerinde olumsuz bir motivasyon yarattığı ve çalışamaya tutkunluğun alt boyutlarından adanmışlı̆̆ı olumsuz yönde etkilediği düşünülmektedir. Bu konuda alan yazın tarandığında liderin uyumsuz mükemmeliyetçiliği ile çalışan tutkunluğu arasında bir çalışmaya rastlanmamıştır.

Araştırmanın son hipotezi değerlendirildiğinde; lidere yönelik mükemmeliyetçilik bakış açısının çalışan tutkunluğu ile performans arasındaki ilişkide düzenleyici bir rolü olmadığı görülmektedir. Fakat bu ana hipotezin alt hipotezlerinden olan liderine yönelik uyumlu mükemmeliyetçilik bakış açısının, çalışan tutkunluğu ile performans arasındaki ilişkide pozitif yönlü düzenleyici bir rolü olduğu görülmüştür. Düzen ve standartlar alt boyutları üzerinden, çalışanın işine adanmış, daha dinç ve işine daha yoğunlaşmış olarak devam ettiği söylenebilir.

Diğer yandan, liderine yönelik uyumsuz mükemmeliyetçilik bakış açısının ise; çalışan tutkunluğu ile performans arasındaki ilişkide düzenleyici bir rolünün olmadığı görülmektedir. Uyumsuz mükemmeliyetçiliğin -tatminsizlik ve çelişki alt boyutlarının- çalışan tutkunluğu ve iş performansı ile negatif yönde ilişkili olduğu tespit edilmiş olsa da; bireyin çalışan tutkunluğunun performansına etkisinde liderine yönelik uyumsuz mükemmeliyetçilik algısının etkisinin olmadığı görülmektedir. Çalışanların liderlerine yönelik olumlu algılarının, mükemmeliyetçilik boyutunda da uyumlu tutum ve davranışlarının, sahip oldukları tutkunluk düzeyiyle etkileşiminden yüksek bir performans ortaya çıktığı görülmekte; ancak liderin uyumsuz bir mükemmeliyetçilik gösteriyor olmasının, çalışan tutkunluğu ile etkileşimiyle performans düzeyi üzerinde anlamlı bir etki yaratmadığı görülmektedir. Bu noktada, liderin uyumsuz mükemmeliyetçiliğine yönelik algının, çalışan tutkunluğunun performansa etkisini azaltııı bir güce sahip olmadığı; çalışan tarafından yalnızca uyumlu boyutun çalışan tutkunluğunun etkisini güçlendirdiği görülmektedir. Diğer deyişle, çalışmaya tutkun olan bireyin, liderinin uyumsuz yönlü mükemmeliyetçiliğine, yani çelişkili ve tatminsiz tutumlarına rağmen motivasyonunu koruduğu ve performansını olumsuz etkilemesine izin vermediği anlaşılmaktadır. Bu noktada çalışan tutkunluğunun, kişide sağladığı dinçlik, adanmışlık ve yoğunlaşmanın, sanıldığından çok daha güçlü bir etkiyle kişinin performansına yönelik koruyucu bir özelliği olduğu anlaşılmaktadır. Yine bu konuda da alanyazında çalışmaya rastlanıımamış olup, literatüre yeni bir katkı sağlamayı hedeflemektedir.

Bu araştırma ile çalışan tutkunluğunun iş performansı ile ilişkisine dair yapılan pek çok araştırmayı destekler nitelikte bulgular öne sürülmekle birlikte; çalışanın liderine yönelik uyumsuz mükemmeliyetçilik özelliklerinin bu ilişkide düzenleyici bir rol oynamadığını göstermektedir. Bu bulgu bize, çalışan tutkunluğunun bireyin iş motivasyonu ve performansı üzerinde, uyumsuz mükemmeliyetçilik özelliklerine sahip bir liderin varlığında dahi, olumlu etkisini 
koruyabildiğini göstermektedir. Buradan hareketle yöneticilerin, çalışanların işlerine tutkunluk düzeylerini besleyecek uyumlu mükemmeliyetçilik özelliklerini ön plana çıkarmasının, çalışanın verimini ve motivasyonu artıracak önemli bir kolaylaştırıcı olduğunun da altı çizilmelidir.

\section{Kaynakça}

Arıkan, S., Çankır, B. (2009). Gıda ve finans sektöründe çalışan performansı hangi faktörlerden etkileniyor? Sürdürülebilir kalite algısı, psikolojik iyi oluş ve çalışmaya tutkunluk değişkenlerinin rolü. Uluslararası Toplum Araştırmaları Dergisi, 18 (12).

Armstrong, M. (2009). Armstrong's handbook of human resource management practice. Kogan Philadelphia.

Barutçugil, i. (2014). Liderlik, İstanbul: Kariyer yayınları.

Başaran, İ.E. (2008). Örgütsel davranış-insanın üretim gücü, Ankara: Siyasal kitabevi.

Bakker, A. B. ve Demerouti, E. (2008). Towards a model of work engagement. Career Development International, 13(3), $209-223$.

Bakker, A. B., M. Tims, ve D. Derks. (2012). Proactive personality and job performance: The role of job crafting and work engagement. Human Relations, 65(10), 1359-1378.

Ben-Sharar, T. (2014), Mükemmeli aramak, Çev.Dr. Bülent Akat, Elma yayınevi, Ankara.

Bieling, P., Israeli, A. L. ve Antony, M. M. (2004), Is perfectionism good, bad or both? Examining models of the perfectionism construct, Personality and Individual Differences, 36(6), 1373-1385.

Borynack, Z. A. (2003). Contextual influences in the relationship of - perfectionism and anxiety: A multidimensional perspective. Yayınlanmamış doktora tezi. Oklahoma Üniversitesi, Oklahoma.

Bousman, L.A. (2007). The fine line of perfectionism: Is it a strength or a weakness in the workplace, the graduate College at the University of Nebraska.

Burns, D. D. (1999). Feeling good: The new mood therapy. Harper.

Christian, M. S., Garza, A. S., \& Slaughter, J. E. (2011). Work engagement: A quantitative review and test of its relations with task and contextual performance. Personnel Psychology, 64(1), 89-136.

Demircioğlu, E. C. (2015). Karizmatik liderliğin yönetsel açıdan değerlendirilmesi. Uluslararası Akademik Yönetim Bilimleri Dergisi, 1(1).

Eren, S. (2013). Mükemmeliyetçiliğin iş performansına etkisi: İstanbul ili uluslararası zincir otel işletmelerinde çalışan orta kademe mutfak yöneticileri üzerine bir araştırma, yayımlanmamış doktora tezi, Dokuz Eylül Üniversitesi, Sosyal Bilimler Enstitüsü, Turizm İşletmeciliği Anabilim Dalı, Turizm işletmeciliği programı, İzmir.

Frost, R. O., Marten, P. A., Lahart, C., \& Rosenblate, R. (1990). The dimensions of perfectionism. Cognitive Therapy and Research, $14,449-468$.

Ghadi, M. Y., Fernando, M., \& Caputi, P. (2013). Transformational leadership and work engagement The mediating effect of meaning in work. Leadership \& Organization Development Journal, 34(6), 532-550.

Ghafoor, A., Tahir M. Q., M. Ashan K. ve Hijazi, S.T. (2011). Transformational leadership, employee engagement and performance: mediating effect of psychological ownership. African Journal of Business Management, 5(17): 7391-7403.

Helvacıoğlu, N. ve Özutku, H. (2010). Kültürel farklılıkların yönetiminde insan kaynakları stratejilerinin rolü: IKEA örneği. Yönetim Bilimleri Dergisi, 2(1), 193216.

Hewitt, R.L. ve Flett, G.L. (1991). Dimensions of perfectionism in unipolar depression. Journal of Abnormal Psychology, 100(2), 98-101.

Hollander, M.H. (1965). Perfectionism. Comprehensive Psychiatry, 6(2), 94-103.

İşler, S.D. (2018). Uyumlu Ve uyumsuz mükemmeliyetçilik özellikleri ve bilişsel duygu düzenleme stratejileri ile depresyon arasındaki ilişkiler, yayımlanmamış yüksek lisans tezi, Maltepe Üniversitesi, İstanbul.

Kahn, W.A. (1990). Psychological conditions of personal engagement and disengagement at work. Academy of Management Journal, 33(4), $694-695$.

Kahn, W.A. (2012). The essence of engagement: Lessons from the field, handbook of employee engagement: Perspectives, issues, research and practice. Cheltenham, Edward Elgar Publishing.

Keser, A. ve Yılmaz, G. (2009). İşe bağlanma (Engagement), içinde: Çalışma yaşamında davranış: Güncel konular, (Ed:Keser, A., Yılmaz, G. ve Yürür, S.). Umuttepe Yayınları: Kocaeli.

Kline, R.B., (2011), Principles and practice of structural equation modelling, 3rd.edition, NY: Guilford Press.

Kıral, E. (2012). İlköğretim okulu yöneticilerinin mükemmeliyetçilik algıSı ve kontrol odağı ile ilişkisi, yayımlanmamış doktora tezi, Ankara Üniversitesi, Eğitim Bilimleri Enstitüsü, Ankara.

Koçel, T. (2018). İşletme yöneticiliği, İstanbul: Beta Basım Yayım.

Levinson, H. (2011). Liderlik psikolojisi, Işs Bankası Yayınları Il.Baskı, İstanbul.

Lockwood, N. R. (2007). Leveraging employee engagement for competitive advantage: H.R.'s strategic role, Research Quarterly: 2- 11.

Lorente, L., Salanova, M., Martinez, I. M. ve Vera, M. (2014). How personel resources predict work engagement and self-rated performance among construction workers: A social cognitive perspective. International Journal of Pychology. 49(3), 200-207.

Pacht, A.R. (1984). Reflections on perfection. American Psychologist, 39, 386-390.

Rawls, J. (1971). A theory of justice, Cambridge, Massachusetts: The Belknap Press Of Harvard University Press.

Rich, B. L., J. A. Lepine, ve E. R. Crawford. (2010). Job engagement: Antecedents and effects on job performance. Academy of Management Journal. 53.3, 617625.

Schaufeli, W. B., Salanova, M., González-Romá, V. ve. Bakker, A.B. (2002). The measurement of engagement and burnout: A confirmatory factor analytic approach, Journal of Happiness Studies, 3: 71-92.

Schaufeli, W. Ve Bakker, A. (2004). UWES Utrecht work engagement scale, Preliminary Manual.

Schneider, B. Ve arkadaşları (2012). The role of employee trust in understanding employee engagement, Handbook of employee engagement: Perspectives, issues, research and practice, Cheltenham, Edward Elgar Publishing.

Şahin, A. ve Temizel, H. (2007). Bilgi toplumunun örgütsel ve yönetsel yapılar üzerine etkileri bağlamında Türk kamu yönetiminde liderlik anlayışı. Maliye Dergisi, 153, 179-194.

Tabak, A. (2012). Liderlik, iş, güç. Endüstri ilişskileri ve Insan Kaynakları Dergisi, 89-106.

Whittaker, P.D. (2002). Perfectionism's relationship to anxiety, epression and attributional style within a stressful task paradigm, Texas Tech University, USA. Yıldız, S. (2015). Lider-üye etkileşimi, işyerinde mobbing ve mesleki tükenmişlik ilişkisi, Ankara: Detay Yayınevi. 